\title{
External Debt and Economic Growth in Transition Countries: Case of Kyrgyzstan
}

\author{
Junus GANIEV ${ }^{1}$, Damira BAIGONUSHOVA ${ }^{2}$, Nurbek MADMAROV ${ }^{3}$ \& \\ Raziiakhan ABDIEVA ${ }^{4}$
}

\section{Abstract}

In many developing countries, out of shortage of savings and capital external resources as external debt, foreign direct investment and transfers play significant role in the fostering economic growth and development. The aim of this paper is to investigate the impacts of external public debt, current transfers and foreign direct investments on GDP of Kyrgyz Republic. By using quarterly data during 2000Q1-2017Q3 and the ARDL estimation method, the long-rum cointegration relationship between current transfers, external debt, FDI and GDP was found. According to the results, current transfers' contribution to the country's economy is more than government debts. It is suggested that the government should focus more on foreign direct investments than foreign debts and current transfers in the long term.

Key Words: External Debt, Foreign Direct İnvestment, Current Transfers, Economic Growth, Kyrgyzstan

\section{Geçiş Ekonomilerinde Dış Borç Ve Ekonomik Büyüme: Kırgızistan Örneği}

\section{Öz}

Birçok gelișmekte olan ülkede tasarruf ve sermaye yetersizliğinden dolayı dış borç, doğrudan yabancı yatırımlar ve transferler gibi dış kaynaklar ekonomik büyüme ve kalkınmanın desteklenmesinde önemli rol oynamaktadır. Bu çalışmanın amacı, Kırgız Cumhuriyeti’nde diş kamu borcunun, cari transferlerin ve doğrudan yabancı yatırımların GSYİH üzerindeki etkisini araştırmaktır. 2000Q1-2017Q3 dönemi çeyrek verileri ve ARDL eşbütünleşme yaklaşımı kullanılarak cari transferler, dış borç, DYY ve GSYIH arasında eşbütünleşme ilişkisi olduğu tespit edilmiştir. Sonuçlara göre, cari transferlerin ülke ekonomisine olan katkısı devlet borçlarından daha yüksektir. Hükümetin uzun vadeyi göz önünde bulundurarak dış borçlara ve cari transferlere göre doğrudan yabancı yatırımların artırılmasına daha fazla odaklanması gerektiği önerilmektedir.

Anabtar Kelimeler: Dış Borç, Doğrudan Yabancı Yatırımlar, Cari Transferler, Ekonomik Büyüme, Kırgızistan

\author{
Atıf İçin / Please Cite As: \\ Ganiev, J., Baigonushova, D., Madmarov, N., \& Abdieva, R. (2020). External debt and economic growth in \\ transition countries: Case of Kyrgyzstan. Manas Sosyal Araștirmalar Dergisi, 9(1), 60-75.
}

Geliş Tarihi / Received Date: 25.06.2019

Kabul Tarihi / Accepted Date: 30.10.2019

\footnotetext{
1 Asst. Prof. Dr. - Kyrgyz-Turkish Manas University, Faculty of Economics and Management, junus.ganiev@manas.edu.kg ORCID: 0000-0001-8859-5464

2 Asst. Prof. Dr. - Kyrgyz-Turkish Manas University, Faculty of Economics and Management, damira.baigonushova@manas.edu.kg- ORCID: 0000-0002-9740-0021

3 PhD Candidate, Kyrgyz-Turkish Manas University, Institute of Social Sciences, nurbekmadmarov17@gmail.com ORCID: 0000-0002-2329-5433

4 Asst. Prof. Dr. - Kyrgyz-Turkish Manas University, Faculty of Economics and Management razia.abdieva@manas.edu.kg ORCID: 0000-0002-9438-1558
} 


\section{Introduction}

Kyrgyzstan is a small, open and externally dependent economy on petroleum products with undeveloped industry. The main exporting products are raw and unprocessed products such as gold, animals, fruit and vegetables. The country's import volume exceeds export volume by about four times. Also, due to the limited job opportunities inside, more than one third of labor force is working abroad.

Because of all these factors, the economic development of the country has become dependent on foreign factors. Thus, the foreign debt, remittances and foreign direct investments make significant contributions to the economic growth. In this regard, by examining the effects of external resources and especially external debts on growth, the aim of this study is to present policy recommendations for the country's economy.

The study consists of the introduction, conclusion and four parts. In the first part, the economic growth and the situation of external debt in Kyrgyzstan will be discussed by presenting statistical data. Then, literature review, sample data and methodology will be presented. At the end based on the results of econometric analysis, some policy proposals will be offered.

\section{Economic Growth and External Debt in Kyrgyzstan}

After the collapse of the USSR, Kyrgyzstan experienced a number of severe shocks. It lost its traditional markets placed in the other Soviet Union countries and substantial subsidies from the Soviet Union. The GDP of the country fell about 50\% during the first five years of independence (World Bank, 2004). Indeed, during early 10 years of transition in the former Soviet Union countries, the average decrease in their economies was 65\%, which was deeper than Global Great Depression. During Great Depression (between 1930 and 1934), the economic downturn in USA, Germany, and France was 27\%, 16\%, and 11\% respectively (Sakinç, 2004: 431). Since 1996, with the beginning of production in mining sector, the Kyrgyzstani GDP began to rise. However, the political shocks in 2005 and 2010 depressed the economy by $0.18 \%$ and $0.47 \%$ respectively. In 2012 and 2014, by excluding the stagnation in the production of gold mining company "Kumtor" and agricultural sector, GDP decreased by $0.09 \%$ (National Bank of Kyrgyz Republic, 2015).

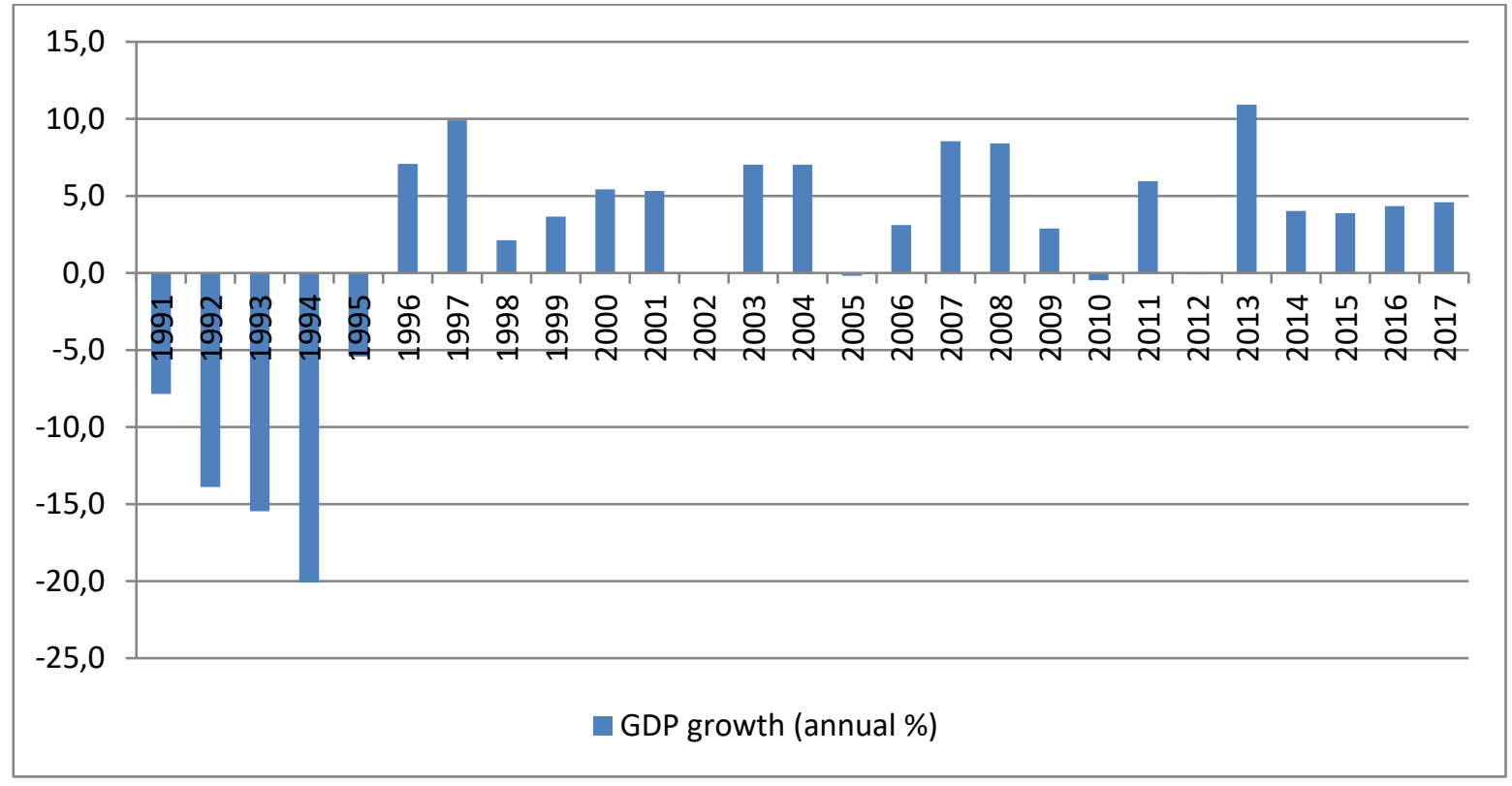

Graph 1. Real GDP Growth in Kyrgyzstan (year over year)

Since 2014, the economic growth is accounted for about 3-4\%. The IMF pointed out that in 2014 15 , several adverse external shocks such as a persistent slump in commodity prices, an abrupt decline in remittances, and lower demand for imported goods from key trading partners, especially China and Russia, hit the Central Asian and Caucasus countries. As a result of all these factors, one of the most two important indicators of an economy's health, the economic growth declined sharply and the current account balances weakened (IMF, 2019). 
In the early years of independence (1991-1995), the hyperinflation and the drop of production in one side and the rising government expenditures for implementing structural reforms caused the budget shortage. Thus, the budget surplus in 1993 (7.1\%) turned into 7.7\% of deficit in 1994 and recovered to 11.5\% in 1995 (Koichuyev, 2003: 86). Between 2000 and 2008, the increase of remittances by the Kyrgyz migrants led to rise of the demand and in the production and this in turn caused the growth in the tax revenues, which resulted in the budget surplus in 2008. Nonetheless, due to the global financial crisis and the political unrest between 2008 and 2013, the budget deficit increased rapidly.

Budget deficit of the country is mostly covered by the debt and especially by the external debt. Nowadays, the ratio of external public debt to GDP is approximately $60 \%$. The Government of Kyrgyz Republic has been dealing with reducing the debt and therefore the budget deficit. The IMF recommends improving effectiveness of using debt and government expenditure, and increasing government revenue through increasing tax base and ensuring higher, sustainable and inclusive growth.

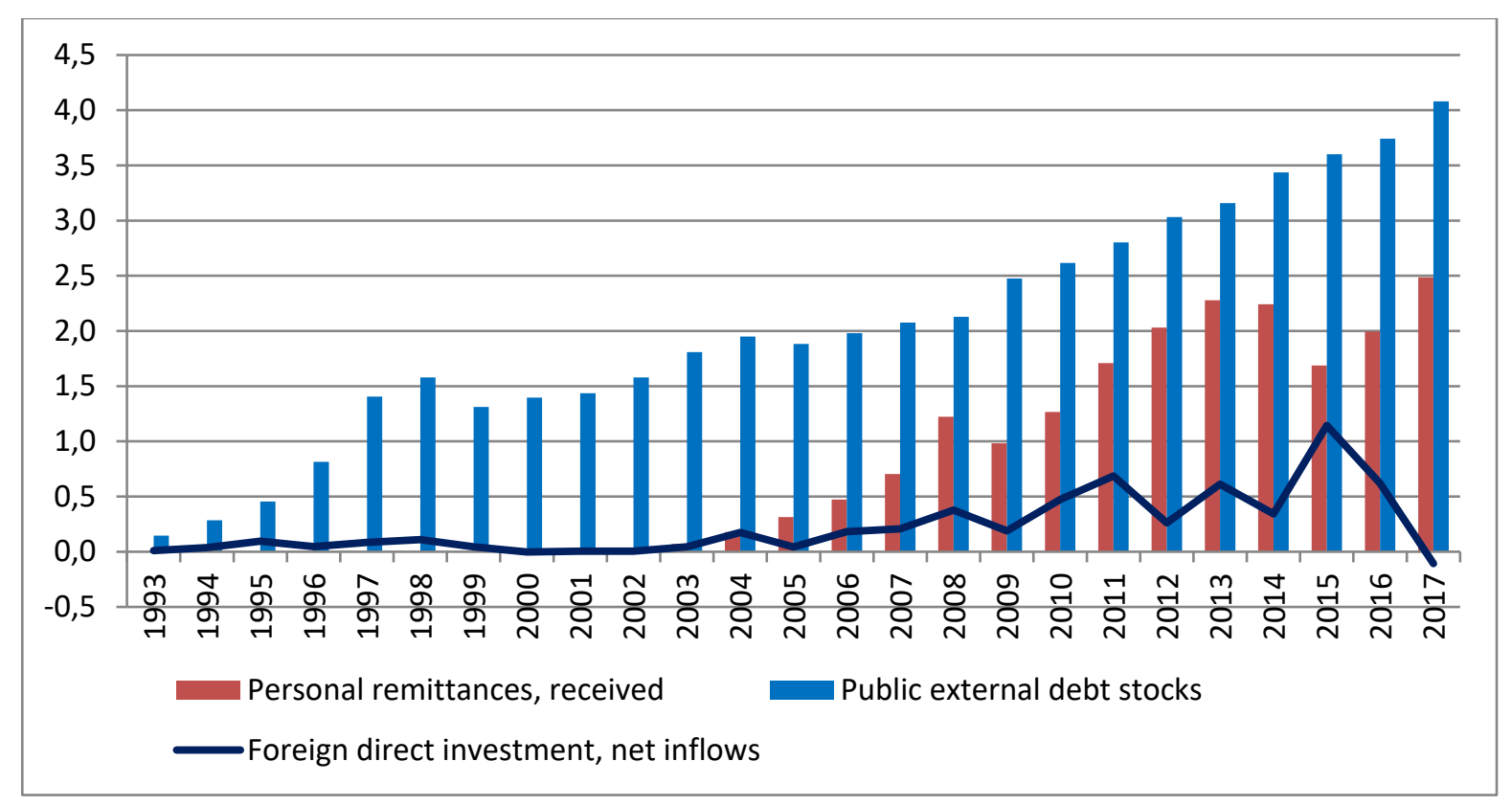

Graph 2. External Resources in Kyrgyzstan (bln. USD)

Nowadays, due to the inadequacy of the internal resources, the Kyrgyz economy depends mostly on the external resources like external debt, foreign direct investments (FDI) and remittances. Furthermore, the significant portion of private investments and of infrastructure investments made by the state are made up of foreign capital and financed by foreign aid and foreign debts. Proportionally, as the share of external aid is naturally low, the infrastructure investments are continuously increasing the burden of future generations. Indeed, the external government debt of Kyrgyzstan has increased by $86 \%$ in the last ten years, from 2.07 to 3.86 billion US dollars. On the other hand, the foreign direct investment contributes to the country's economy by not directly increasing the debt burden. Moreover, the current transfers, which mostly consisting of workers' remittances, is an important external source for Kyrgyzstan as well.

According to the National Statistics Committee of the Kyrgyz Republic (NSCKR), the amount of foreign direct investments in the country during the period of 1995-2016 reached to 9.89 billion US dollars. One fifth of this, 1.79 billion US dollars, came to be partners with existing joint-stock companies or to form a new joint-stock company. Other than this, exactly $20 \%$ is of re-investments; $44 \%, 3.99$ billion dollars, is of foreign capital investors' loans; $14.6 \%$ is of commercial loans; $1.65 \%$ is of financial leasing and other capital. The average annual amount of FDI in the last ten years is about 800 million US dollars.

During 1995-2015, 6.85 (75.5\%) and $2.22(24.5 \%)$ billion US dollars of FDI were provided by nonCIS countries and the CIS countries respectively. The largest investor countries and their shares are: Canada (19.75\%), China (18.86\%), Kazakhstan (13.01\%), Russia (10.60\%), United Kingdom (10.08\%), Turkey (5.00\%), Germany (4.06\%), and the USA (3.04\%). 
Since the classification of foreign direct investments by sectors was changed several times by the NSCKR, it was not possible to examine them in an aggregate form before 2008. During 2008-2015, the rank of the sectors that attracted foreign direct investment was (i) the manufacturing industry $(38.02 \%)$, (ii) occupational, scientific and technical activities $(25.45 \%)$, (iii) financial and insurance activities $(18.30 \%)$, (iv) trade and motor vehicles repair $(6.22 \%)$, (v) construction $(3.76 \%)$, (vi) electricity, gas, and steam energy $(2.84 \%)$, and (vii) mining sectors $(2.60 \%)$. In other words, the investments generally come to the industry and services sectors such as food, construction, banking, mining, trade, and education.

When we look at the distribution of Kyrgyzstan's foreign debt by countries and institutions, it is seen that China Export-Import Bank ranks first with a share of $44.5 \%$ for infrastructural investments such as electricity and highways. Our debt to this institution has increased rapidly in the last five years. The second and third lenders are the World Bank with a share of $18.2 \%$ and the Asian Development Bank with a share of $16.7 \%$ respectively. A significant portion of these resources has also been used for the highways.

In 2016, 3.5 billion US dollars volume of total external debt consisted of $58.4 \%$ of bilateral and $40.2 \%$ of multilateral loans, which means $98.6 \%$ of the total debt consists of privileged debts (for more detailed information see Appendix 1). It should emphasized that even though this seems to be beneficial, due to its longer duration and lower interest rates, for the country's economy, it should still be repaid in some time in the future. Hence, in the upcoming period more emphasis should be placed on encouraging private capital in the form of public-private partnership for the investment of infrastructure expenditures. In our opinion, it is one of the important measures that will lead to the country to avoid the rapidly increasing total external debt.

\section{Literature Review}

Most of the countries that try to improve their economy come across with the problem of inadequacy of internal resources and accordingly, resort to external resources. In this case, the most important external sources can be external debt and foreign direct investment. Since foreign direct investment has some important advantages over foreign debt, countries prefer to attract foreign investors. However, some countries, especially when they cannot find sources for infrastructural investment or cover budget deficits with domestic debt, resort to external borrowing.

Nevertheless, there is no consensus among both theoretical and empirical studies about the impact of external debt on economic growth. The theoretical literature was mostly developed after the 1980s debt crisis in Latin America. The intertemporal borrowing model, the debt-led growth model and debt surplus theory can be given as an example for this literature. Bilginoğlu and Aysu (2008) have studied these approaches in detail.

The contribution of FDI to economic growth is one of the most frequently discussed topics in the literature. According to the traditional argument, while FDI contributes to economic growth by increasing capital stock, in more up to date studies, it is viewed as an instrument for international technology transfer (Lensink and Morrissey, 2001: 3). To sum up, FDI contributes to an economy or/and hereby to economic growth significantly. However, it is also indisputable that portfolio investments may have various negative effects on an economy.

Abdelhafidh (2014) investigated the effect of external debt on economic growth for Tunisia during 1970-2010, and found that external debt affects economic growth both in the short and long-run significantly. He proposed that the advantage of external debt on the growth should be used for Tunisia. Akbas et al. (2013) examined the causal relationship between FDI, current account deficit, total credits and GDP for the G7 countries by Dumitrescu and Hurlin panel cointegration test. The results showed that there was a unidirectional causality from the current account deficit and FDI to economic growth. He suggested finding the ways to support for FDI to make current accounts more sustainable. Some empirical studies on these issues are summarized in three subheadings in accordance with the subject and given in Table 1. 
Table 1. Some Empirical Studies Investigating the External Debt, Foreign Direct Investment, and Economic Growth

\begin{tabular}{|c|c|c|c|}
\hline $\begin{array}{c}\text { Authors and Paper } \\
\text { publication year }\end{array}$ & Country and period & Method & Results \\
\hline \multicolumn{4}{|c|}{ Empirical Studies Investigating the Effect of Foreign Debt and Foreign Direct Investments on Economic Growth } \\
\hline Ebru Yalçın (2005) & $\begin{array}{l}\text { East Asia-Pacific, Europe and } \\
\text { Central Asia, Latin America } \\
\text { and the Caribbean, the Middle } \\
\text { East and North Africa, South } \\
\text { Asia and Africa, } 31 \text { countries } \\
\text { from } 6 \text { regions; 1982-2003 }\end{array}$ & $\begin{array}{l}\text { LSDV and TIME } \\
\text { Panel data analysis }\end{array}$ & $\begin{array}{l}\text { While investment inflows affect } \\
\text { economic growth positively, debt } \\
\text { components affect the growth } \\
\text { negatively. }\end{array}$ \\
\hline $\begin{array}{l}\text { Bolanle Azeez, Fapetu } \\
\text { Oladapo, Olufemi A. } \\
\text { Aluko (2015) }\end{array}$ & Nigeria; 1990-2013 & $\begin{array}{l}\text { Error } \quad \text { correction } \\
\text { model }\end{array}$ & $\begin{array}{l}\text { While there is a significant positive } \\
\text { relationship between foreign direct } \\
\text { investment and growth, there is a } \\
\text { negative but insignificant relationship } \\
\text { between external debt and economic } \\
\text { growth. }\end{array}$ \\
\hline $\begin{array}{l}\text { Moga Tano Jilenga, } \\
\text { Helian Xu, Igor- } \\
\text { Mathieu Gondje-Dacka }\end{array}$ & Tanzania; 1971-2011 & $\begin{array}{l}\text { ARDL cointegration } \\
\text { approach }\end{array}$ & $\begin{array}{l}\text { While foreign debt significantly } \\
\text { contributes to economic growth, FDI } \\
\text { negatively affects the growth. }\end{array}$ \\
\hline
\end{tabular}

\begin{tabular}{|c|c|c|}
\hline \multicolumn{3}{|c|}{ Empiric Studies Investigating the Relationship Between External Debt } \\
\hline $\begin{array}{l}\text { Siddique, A., } \\
\text { Selvanathan E. A. and } \\
\text { Selvanathan S. (2015) }\end{array}$ & $\begin{array}{l}\text { Forty HIPC countries; 1970- } \\
2007\end{array}$ & Panel ARDL \\
\hline $\begin{array}{l}\text { Mehmet Ali Bilginoğlu, } \\
\text { Ahmet Aysu (2008) }\end{array}$ & Turkey; 1968-2005 & $\begin{array}{l}\text { Ordinary } \\
\text { Squares (OLS) }\end{array}$ \\
\hline $\begin{array}{l}\text { Ekrem Gül, Ahmet } \\
\text { Kamac1 and Serkan } \\
\text { Konya (2012) }\end{array}$ & $\begin{array}{l}\text { Azerbaijan, } \quad \text { Kazakhstan, } \\
\text { Kyrgyzstan, Uzbekistan, } \\
\text { Tajikistan, Turkmenistan, and } \\
\text { Turkey; 1994-2010 }\end{array}$ & $\begin{array}{l}\text { Pedroni Cointegration } \\
\text { Test and Panel } \\
\text { Granger Causality } \\
\text { Test }\end{array}$ \\
\hline
\end{tabular}

and Economic Growth

External debt affects economic growth negatively.

Selvanathan S. (2015)

Foreign debt has a negative impact on economic growth.

In the long run, a unilateral causality from foreign debt to growth has been identified.

However, the nonexistence of the short-run relationship can be explained by the increasing debt burden after gaining independence of the Turkic Republics.

\begin{tabular}{|c|c|c|c|}
\hline $\begin{array}{l}\text { Murat Karagoz and } \\
\text { Mehmet Caglar (2016) }\end{array}$ & Seventeen OECD countries & $\begin{array}{l}\text { FEM, REM, and } \\
\text { Pooled OLS }\end{array}$ & $\begin{array}{l}\text { The positive impact between foreign } \\
\text { debt and economic growth was found. } \\
\text { It may be led by effective debt } \\
\text { management. }\end{array}$ \\
\hline $\begin{array}{l}\text { Sinem Kutlu and } \\
\text { İpek M. Yurttagüler } \\
(2016)\end{array}$ & Turkey; 1998:01-2014:02 & $\begin{array}{l}\text { Granger Causality, } \\
\text { Johansen } \\
\text { Cointegration Test }\end{array}$ & $\begin{array}{l}\text { Foreign debt has been found as one of } \\
\text { the most important dynamics of } \\
\text { economic growth in Turkey. }\end{array}$ \\
\hline $\begin{array}{l}\text { Noraznin Abu Bakar } \\
\text { and } \quad \text { Sallahuddin } \\
\text { Hassan (2008) }\end{array}$ & Malaysia; 1970-2005 & $\begin{array}{l}\text { VAR approach, } \\
\text { Johansen } \\
\text { Cointegration Test }\end{array}$ & $\begin{array}{l}\text { Total external debt has positive impact } \\
\text { on growth. Every } 1 \% \text { increase in the } \\
\text { foreign debt accumulation leads to a } \\
1.29 \% \text { increase in economic growth. }\end{array}$ \\
\hline $\begin{array}{lr}\text { Rashid } & \text { Zaman, } \\
\text { Muhammad } & \text { Arslan } \\
(2014) & \\
\end{array}$ & 1972-2010 & OLS regression & $\begin{array}{l}\text { External debt has a positive effect on } \\
\text { GDP growth. }\end{array}$ \\
\hline Ogunmuyiwa (2011) & Nigeria; $1970-2007$ & OLS regression & $\begin{array}{l}\text { The effect of foreign debt on growth is } \\
\text { very weak and statistically insignificant. }\end{array}$ \\
\hline $\begin{array}{l}\text { Temel Gürdal and } \\
\text { Hakan Yavuz (2015) }\end{array}$ & Turkey; 1990:Q1-2013:Q12 & $\begin{array}{l}\text { Gregory-Hansen } \\
\text { Cointegration } \\
\text { approach (1996), } \\
\text { Hacker and Hatemi-J } \\
\text { Causality Tests (2006) }\end{array}$ & $\begin{array}{l}\text { A unidirectional causality from growth } \\
\text { to foreign debt has been determined. } \\
\text { An increase of } 1 \% \text { in the economic } \\
\text { growth increases the foreign debt by } \\
0.0013 \% \text {. }\end{array}$ \\
\hline $\begin{array}{l}\text { Bernd Kempa and } \\
\text { Nazmus Sadat Khan } \\
(2016)\end{array}$ & G7 Countries; 1980-2013 & $\begin{array}{l}\text { Toda and Yamamoto } \\
\text { Causality Test }\end{array}$ & $\begin{array}{l}\text { Economic growth is the cause of } \\
\text { increased foreign debt. }\end{array}$ \\
\hline
\end{tabular}
(2016)

Empirical Studies Investigating the Relationship between FDI and Economic Growth

\begin{tabular}{|c|c|c|c|c|}
\hline $\begin{array}{l}\text { Hasan Vergil, Coşkun } \\
\text { Karaca (2010) }\end{array}$ & $\begin{array}{l}\text { Twenty-five developing } \\
\text { countries; 1980-2005 }\end{array}$ & $\begin{array}{l}\text { FEM Panel } \\
\text { analysis }\end{array}$ & data & $\begin{array}{l}\text { Whereas both the impact of foreign } \\
\text { direct investment and portfolio } \\
\text { investments on growth is positive, the } \\
\text { impact of short-term capital } \\
\text { investments on growth is found to be } \\
\text { negative. }\end{array}$ \\
\hline Afşar (2008) & Turkey; 1992:1-2006:3 & Granger & ality & There is a causal relationship from \\
\hline
\end{tabular}




\begin{tabular}{|c|c|c|c|}
\hline & & Test & $\begin{array}{l}\text { foreign direct investments to economic } \\
\text { growth. }\end{array}$ \\
\hline $\begin{array}{l}\text { Alfaro L. and Charlton } \\
\text { A. (2007) }\end{array}$ & $\begin{array}{l}\text { Twenty-nine countries; } 1985- \\
2000\end{array}$ & IV Panel Regression & $\begin{array}{l}\text { Foreign direct investment affects the } \\
\text { sectorial value added positively. }\end{array}$ \\
\hline İbrahim Örnek (2008) & Turkey; 1996:4-2006:1 & $\begin{array}{l}\text { Johansen-Juselius } \\
\text { Multiple Cointegration } \\
\text { Test, VAR Approach }\end{array}$ & $\begin{array}{l}\text { Both of short-term capital inflows and } \\
\text { FDI has a positive impact on the } \\
\text { economic growth. }\end{array}$ \\
\hline $\begin{array}{l}\text { Balasubramanyam, } \\
\text { Solisu and Sapsford } \\
(1996)\end{array}$ & Forty-six countries; 1970-1985 & $\begin{array}{l}\text { Cross sectional } \\
\text { regression analysis }\end{array}$ & $\begin{array}{l}\text { In the open economies, there exists } \\
\text { FDI based growth. }\end{array}$ \\
\hline $\begin{array}{l}\text { Lensink and Morrissey } \\
\text { (2001) }\end{array}$ & $\begin{array}{l}\text { Developing countries; } 1975- \\
1998\end{array}$ & $\begin{array}{l}\text { Cross Section and } \\
\text { Panel Regression }\end{array}$ & $\begin{array}{l}\text { Foreign direct investment based growth } \\
\text { is valid. }\end{array}$ \\
\hline $\begin{array}{l}\text { Basu P., Chakraborty } \\
\text { C. and Reagle D. } \\
\text { (2003) }\end{array}$ & $\begin{array}{l}\text { Twenty-three developing } \\
\text { countries; 1978-1996 }\end{array}$ & $\begin{array}{lr}\text { Pedroni } & \text { Panel } \\
\text { Cointegration } & \text { and } \\
\text { Causality } & \end{array}$ & $\begin{array}{l}\text { It was found a bidirectional relationship } \\
\text { between growth and FDI. }\end{array}$ \\
\hline $\begin{array}{l}\text { Anwar S. and Nguyen } \\
\text { L.P. (2010) }\end{array}$ & Vietnam; 1996-2005 & Panel GMM & $\begin{array}{l}\text { It was found bilateral relations between } \\
\text { growth and FDI. }\end{array}$ \\
\hline Hsiao and Shen (2003) & $\begin{array}{l}\text { Twenty-three developing } \\
\text { countries; 1976-1997 }\end{array}$ & Regression Analysis & $\begin{array}{l}\text { There are bilateral relations between } \\
\text { GDP and FDI. }\end{array}$ \\
\hline Aygül Dönmez (2009) & Turkey; $1950-2004$ & $\begin{array}{l}\text { Two Stage and } \\
\text { Ordinary Regression } \\
\text { analysis }\end{array}$ & $\begin{array}{l}\text { Since foreign direct investment is not } \\
\text { canalized to sectors and regions that } \\
\text { may be profitable for the country, there } \\
\text { is no growth effect. }\end{array}$ \\
\hline Merve Acar (2016) & Turkey; 2001-2015 & Granger Causality & $\begin{array}{l}\text { There is no relation between foreign } \\
\text { investment and economic growth due } \\
\text { to the high proportion of the portfolio } \\
\text { investments in capital accounts. }\end{array}$ \\
\hline $\begin{array}{l}\text { Hamza Çeştepe, } \\
\text { Ertuğrul Yıldırım, } \\
\text { Melike Bayar (2013) }\end{array}$ & Turkey; 1974-2011 & $\begin{array}{l}\text { Toda-Yamamoto } \\
\text { Causality }\end{array}$ & $\begin{array}{l}\text { There is a causal relationship from } \\
\text { GDP to exports; from exports to } \\
\text { foreign direct investments and from } \\
\text { imports to exports. }\end{array}$ \\
\hline
\end{tabular}

Source: Created by authors.

Accordingly, some studies have examined the effects of both external debt and FDI on economic growth. Such studies have generally reached to the conclusion that while external borrowing affects growth negatively, FDI affects positively. On the other hand, there are also studies that have completely opposite results to the previous ones.

According to some studies in case of HIPC countries and Turkey, foreign debt adversely affects the economic growth. But many empirical studies on developing countries have reached the conclusion that external debt has a positive impact on growth. Some researchers have expressed that such a result may be due to effective debt management.

Finally, there are many empirical studies investigating the effects of foreign investment on economic growth. Some researches taking the case of Turkey have not found any relationship between the foreign investments and economic growth. Contrary to this, it has been empirically confirmed that FDI affects growth positively both in developing and developed countries.

In summary, whereas external debt can contribute positively to economic growth in some countries, it affects negatively the growth in others. Nonetheless, it is approved that FDI generally affects growth positively, and in some cases, there is no clear effect.

There was no empirical study in case of Kyrgyzstan using time series analysis. A single panel data study on Turkic Republics was found. This study examined only the effect of external debt on growth and found a unilateral long-term causal relationship from external debt to growth. Therefore, this topic has been chosen both in order to test the validity of the result and to empirically investigate the effect of FDI and foreign debt on economic growth of the Kyrgyz Republic.

\section{Method}

Ordinary least squares is only used when stationary variables are used in a model. However, in most cases, time series variables are proved to be non-stationary whose means and variances are not constant over time or have a unit root. Due to the existence of random shocks, they follow a random walk or random walk with drift processes (Nelson and Plosser, 1982). As a result of all these, the variables used in 
an OLS model seem to have a high degree of relationship while they do not have. We call this issue as a spurious regression. Then to avoid this, we need to use stationary variables or the stationary form of the variables. To decide whether a stochastic process is stationary or not (or has a unit root), Augmented Dickey Fuller (ADF) unit root test is used. The test for autoregressive process with p lags looks like as the following:

$$
\Delta y_{t}=\delta x_{t}^{T}+\alpha y_{t-1}+\beta_{1} \Delta y_{t-1}+\beta_{2} \Delta y_{t-2}+\ldots+\beta_{p} \Delta y_{t-p}+\varepsilon_{t}
$$

where $x_{t}^{T}$ denotes for the vector of exogenous variables which includes a constant or constant and time trend, $\varepsilon_{t}$ is a White Noise process with 0 mean and fixed variance $\sigma_{\varepsilon}^{2}$, $\Delta$ denotes for a first difference operator. Here, the hypotheses are

$$
\begin{aligned}
& H_{0}: \alpha=1 \text { (the series has a unit root) } \\
& H_{1}: \alpha<1 \text { (the series is stationary (around a constant or/and trend)) }
\end{aligned}
$$

which, in turn uses the test statistic $t_{\alpha}=\frac{\widehat{\alpha}}{\operatorname{se}(\widehat{\alpha})}$

where $\widehat{\alpha}$ is an estimate of $\alpha$ and se( $\widehat{\alpha})$ shows the standard error of $\widehat{\alpha}$. Under the null hypothesis, it does not follow the Student t-distribution (Dickey and Fuller, 1979). MacKinnon (1991, 1996) use simulations to derive the response surfaces for Dickey-Fuller critical values for arbitrary sample sizes. All these, and most recent MacKinnon critical values are available on EViews program package.

Here Fuller showed that asymptotic distribution of the t-value does not depend on the number of lagged first differenced variables. Also, when the irrelevant exogenous variables are added to the model, it may decrease the test power of rejecting the null hypothesis. To solve this, a feasible type of the data for the hypotheses should be added to the model (Hamilton, 1994).

The second conventional unit root test is of Phillips and Perron (PP) (Phillips and Perron, 1988). They suggest using nonparametric method to take control over a serial correlation. Their test uses the modified version original Dickey and Fuller unit root test equation, $\Delta y_{t}=\alpha y_{t-1}+\delta x_{t}^{\prime}+\varepsilon_{t}$, as the following:

$$
\widetilde{\mathrm{t}_{\alpha}}=\mathrm{t}_{\alpha}\left(\frac{\gamma_{0}}{\mathrm{f}_{0}}\right)^{1 / 2}-\frac{\mathrm{T}\left(\mathrm{f}_{0}-\gamma_{0}\right) \operatorname{se}(\widehat{\alpha})}{2 \mathrm{f}_{0}^{1 / 2} \operatorname{ser}}
$$

Where $\widehat{\alpha}$ is the estimate, and $t_{\alpha}$ is the t-value of $\alpha$ in the Dickey-Fuller test, $\operatorname{se}(\widehat{\alpha})$ is a standard error of $\widehat{\alpha}$, and ser is the standard error of the regression. Furthermore, ${ }^{\gamma_{0}}$ is a consistent estimate of the error variance, $\frac{(\mathrm{T}-\mathrm{k}) \mathrm{s}^{2}}{\mathrm{~T}}$. Lastly, $\mathrm{f}_{0}$ is an estimator of the residual spectrum at zero frequency. Here the hypotheses are

$$
\begin{aligned}
& H_{0}: \alpha=1 \text { (the series has a unit root) } \\
& H_{1}: \alpha<1 \text { (the series is stationary (around a constant or/and trend)) }
\end{aligned}
$$

Where there is a difference in the test statistics. However, the distribution of the PP test statistics approaches to the ADF test statistic when number of observations increases without bound. The left tail critical values and their $\mathrm{p}$-values are calculated by MacKinnon.

The conventional tests are designed to catch the unit root in a trend (and/or a constant), so they fail to catch the structural breaks in the series. Thus, they may lead to the wrong decision rule(s) about the stationarity of the series; that is to say they may be unsuccessful to reject the null hypothesis if the series has a structural break. According to these tests, the variables which are stationary around the break in a level form seem to be behaving as if they are first difference stationary. To avoid these, the exogenous (dummy) variables should be added into the ADF unit root test to represent structural breaks (Perron, 1989). Zivot and Andrews (1992) advised to add the structural breaks as the endogenous variables; that is to say they should not be added outside the model, instead the model mechanisms should decide in which date the structural breaks take place (Zivot and Andrews, 1992). Three approaches are used: 


$$
\begin{aligned}
& \Delta y_{t}=c+\alpha y_{t-1}+\beta t+\gamma D U_{t}+\sum_{j=1}^{k} d_{j} \Delta y_{t-j}+\varepsilon_{t} \\
& \Delta y_{t}=c+\alpha y_{t-1}+\beta t+\theta D T_{t}+\sum_{j=1}^{k} d_{j} \Delta y_{t-j}+\varepsilon_{t} \\
& \Delta y_{t}=c+\alpha y_{t-1}+\beta t+\gamma D U_{t}+\theta D T_{t}+\sum_{j=1}^{k} d_{j} \Delta y_{t-j}+\varepsilon_{t}
\end{aligned}
$$

where the first, second, and third models allow for a one period change in the intercept, trend, and intercept and trend of the dependent variable respectively. Also, DUt and DTt are the dummy variables that represent breaks in the intercept and trend of the dependent variable respectively:

$$
D U_{t}=\left\{\begin{array}{l}
1 \ldots . . . \text { if } t>T B \\
0 \ldots . . . \text { otherwise }
\end{array}\right\} \text { and } D T_{t}=\left\{\begin{array}{l}
t-T B \ldots . . . \text { if } t>T B \\
0 \ldots . . . \text { otherwise }
\end{array}\right\}
$$

The relevant hypotheses are as the following:

$$
\begin{aligned}
& H_{0}: \alpha=0 \text { (the series has a unit root) } \\
& H_{1}: \alpha<0 \text { (the series is stationary around a structural break) }
\end{aligned}
$$

The model takes every time period as a potential structural break and chooses date as the break point in which the date has the minimum test statistic for $\widehat{\alpha}=1$ where $\widehat{\alpha}=\alpha-1$ (Zivot and Andrews, 1992).

In our analysis, at first the Zivot-Andrews test results are calculated. The significant structural break dates are included as the dummy variables into the necessary models. Then to check the degree of integration, the conventional unit root tests are calculated.

The model can be shown by using a general function:

$$
\ln \mathrm{Y}=\mathrm{f}\left(\ln \mathrm{X}^{\mathrm{m}}\right)
$$

where, $\ln Y$ and $\ln \mathrm{X}^{\mathrm{m}}$ are natural logarithms of the relevant dependent and vector of $\mathrm{m}$ independent variables. The coefficients are in the form of elasticities.

In the study, the quarterly data for the period of 2000Q1-2017Q3 is obtained from the websites of the National Statistical Committee of the KR (NSCKR) and the National Bank of the KR. The dependent variable is log of GDP in constant 2010 million US dollars (USD) (Nominal GDP over CPI (2010=100) of the US), and the independent variables are logs of Current Transfers (CT), Direct Investments (FDI), Loans to Government (GL) and Private Sector (PL) in constant 2010 million USD.

Here Autoregressive Distributed Lag (ARDL) model by Pesaran and Pesaran (1997) will be used as it has advantages over other models like Vector Error Correction, and Vector Auto Regressive Models: (i) It can be estimated by using variables with mixed order of integration (Pesaran and Pesaran, 1997). That is to say they can be either I(0) or/and I(1), (ii) Dynamic relationship between the dependent and independent variables can be obtained by taking sufficient number of lags, (iii) Pesaran et al. (2001)'s "conditional error correction model" can be estimated by the ARDL framework which in turn combines short run relationships with long run equilibrium without losing any necessary information (Pesaran et al., 2001), (iv) Contrary to the Johansen and Joselius's cointegration test, it can be applied to the models with small samples, (v) It weakens the endogeneity problem, and removes it and serial correlation as well (Pesaran and Shin, 1999).

ARDL framework is

$$
\Delta \ln Y_{t}=\beta_{0}+\sum_{i=1}^{p} \alpha_{i} \Delta \ln Y_{t-i}+\sum_{j=1}^{q_{m}} \delta_{i}^{m} \Delta \ln X^{m}{ }_{t-j}+\lambda_{0} \ln Y_{t-1}+\lambda_{m} \ln X^{m}{ }_{t-1}+v_{t}
$$


where $\beta 0$ is a constant and vt is a well-behaved white noise process, $\ln Y$ is a dependent variable, and $\ln \mathrm{Xm}$ denote for $\mathrm{m}$ different independent variables. The $\alpha$ and $\delta$ shows short-run coefficients, $\lambda_{m}$ show long-run coefficient of mth independent variable. The long-run coefficients can be calculated as $(\lambda \mathrm{m} / \lambda 0)$ for each control variable $\mathrm{m}$.

The starting step is the ARDL Bounds Test in which

H0: $\lambda_{0}=\lambda_{m}=0$ (No long-run relationship between the dependent $(\ln \mathrm{Y}$ ) and $\mathrm{m}$ independent variables $(\ln \mathrm{Xm}))$

H1: $\lambda_{0} \neq \lambda_{m} \neq 0$ (Long-run relationship between the dependent $(\ln \mathrm{Y}$ ) and $\mathrm{m}$ independent variables $(\ln \mathrm{Xm}))$.

Since the variables in the model may be either level or first difference stationary, the critical values computed by Pesaran et al. (2001) are used. There are upper and lower bound values. If calculated Fstatistic is smaller than the lower bound value, then cointegration does not exist. If it bigger than the upper bound value, then there exists cointegration between the dependent and independent variables. If it is between these values, then the test is indecisive (Pesaran and Pesaran, 1997). However, since these critical values are established for a large number of observations, the critical values are recalculated by Narayan (2005) for lower number of observations where they are between 30 and 80. Since in our data sample consists of 71 number of observations, we use the critical values by Narayan.

To specify optimal lags for the variables, the ARDL estimates $(p+1) k$ and $(q+1) \operatorname{lm}$ number of different models respectively. Here $\mathrm{p}$ and $\mathrm{lm}$ shows the maximum number of lags for the dependent and $\mathrm{m}$ independent variables chosen by relevant information criterion. Since there are 71 number of observations, AIC is preferred instead of SIC which chooses more parsimonious models.

The short-run model or unrestricted error correction model can be as the following:

$$
\Delta \ln Y_{t}=\beta_{0}+\sum_{i=1}^{p} \alpha_{i} \Delta \ln Y_{t-i}+\sum_{j=1}^{q_{m}} \delta_{i}^{m} \Delta \ln X^{m}{ }_{t-j}+\phi E C T_{t-1}+v_{t}
$$

where the coefficient of lagged error correction term, $\phi$, represents the speed of adjustment to reach the long-run equilibrium. From this value, the time needed for the half of the disequilibria in the short-run to be canceled (half-life) can be calculated as

$$
t_{1 / 2}=\frac{\ln (0.5)}{\phi}=\frac{0.693}{\phi}
$$

Lastly, to comment on the reliability of the model estimates, diagnostic tests for serial correlation, heteroscedasticity, normality, and functional form misspecification are performed. Five number of lag length and AIC is used in all of the tests (Zivot-Andrews, ADF, and ARDL).

\section{Model Estimation Results and Discussions}

Firstly, the Zivot-Andrews structural stationarity test is performed, and the results are recorded in the following table.

\begin{tabular}{|c|c|c|c|}
\hline \multirow[t]{2}{*}{ Variable } & \multicolumn{3}{|c|}{ Structural Break Type } \\
\hline & Intercept & Trend & Both \\
\hline $\operatorname{lnGDP}$ & $-2.73-2015 \mathrm{Q} 1$ & $-3.25-2012 Q 3$ & $-3.31-2010 \mathrm{Q} 4$ \\
\hline $\ln G L$ & $-9.03-2010 \mathrm{Q} 3^{* * *}$ & $-8.52-2006 \mathrm{Q} 3^{* * *}$ & $-9.51-2009 \mathrm{Q} 1^{* * *}$ \\
\hline $\operatorname{lnFDI}$ & $-6.48-2013 \mathrm{Q} 4 * * *$ & $-5.91-2011 \mathrm{Q} 2^{* * *}$ & $-7.03-2013 \mathrm{Q} 4 * * *$ \\
\hline $\ln C \mathrm{~T}$ & $-3.09-2003 \mathrm{Q} 3$ & $-5.28-2007 \mathrm{Q} 1 * * *$ & $-4.84-2007 \mathrm{Q} 2 *$ \\
\hline $\ln \mathrm{PL}$ & $-3.994-2006 \mathrm{Q} 3$ & $-3.21-2008 \mathrm{Q} 3$ & $-5.24-2007 \mathrm{Q} 1^{* *}$ \\
\hline
\end{tabular}

Table 2. Zivot-Andrews Structural Unit Root Test Results

Note: $* * *, * *$ and $*$ indicate significance levels of $1 \%, 5 \%$ and $10 \%$ respectively. 
Source: computed by authors using Eviews9.

The variables except lnGDP have at least one structural break either in one of the intercept, trend, or both. The dummy variables are included in the analysis to control the effect of the structural breaks, and to avoid decreasing the test power. In addition to this, Table 3 below presents the results for conventional unit root tests.

Table 3. Conventional Unit Root Test Results (Max.lag=4, AIC)

\begin{tabular}{|c|c|c|c|c|}
\hline \multirow[b]{2}{*}{ Variables } & \multicolumn{2}{|c|}{ Augmented Dickey-Fuller (ADF) } & \multicolumn{2}{|c|}{ Phillips-Perron (PP) } \\
\hline & Intercept & Trend and intercept & Intercept & Trend and intercept \\
\hline \multicolumn{5}{|c|}{ LEVEL } \\
\hline $\operatorname{lnGDP}$ & -1.66 & -0.65 & -1.87 & -0.47 \\
\hline $\operatorname{lnGL}$ & $-3.33 * *$ & $-7.41 * * *$ & $-5.46^{* * *}$ & $-7.3^{* * * *}$ \\
\hline $\operatorname{lnFDI}$ & $-5.91 * * *$ & $-5.82 * * *$ & $-5.5^{* * *}$ & $-5.95^{* * *}$ \\
\hline $\operatorname{lnCT}$ & -1.49 & -0.72 & -1.02 & -1.56 \\
\hline $\ln P L$ & -1.39 & -1.22 & -1.67 & -3.21 \\
\hline \multicolumn{5}{|c|}{ FIRST DIFFERENCE } \\
\hline$\Delta \operatorname{lnGDP}$ & $-5.72 * * *$ & $-5.98 * * *$ & $-5.79 * * *$ & $-5.9 * * *$ \\
\hline$\Delta \operatorname{lnGL}$ & $-6.51 * * *$ & $-6.5^{* * *}$ & & \\
\hline$\Delta \operatorname{lnFDI}$ & $-7.9^{* * *}$ & $-7.85^{* * *}$ & & \\
\hline$\Delta \ln C \mathrm{~T}$ & $-3.38^{* *}$ & $-15.01 * * *$ & $-13.81 * * *$ & $-14.32^{* * *}$ \\
\hline$\Delta \ln P L$ & $-8.82 * * *$ & $-8.84 * * *$ & $-14.67 * * *$ & $-14.63 * * *$ \\
\hline
\end{tabular}

Note: $* * *, * *$ and $*$ indicate significance levels of $1 \%, 5 \%$ and $10 \%$ respectively.

Source: computed by authors using Eviews9.

According to the results, it is found that the two variables (lnGL and $\operatorname{lnFDI}$ ) are level stationary, $\mathrm{I}(0)$, and the others are first difference stationary, I(1). Then the preliminary condition for ARDL model is satisfied. Therefore, all these variables can be used to estimate ARDL model.

According to the ARDL bounds test, if the calculated F-statistics is greater than the upper bound I(1) critical value created by Pesaran et al. (2001), then the cointegration relationship between these series exists.

Table 4. ARDL Bounds Test Results (Max.lag=4, AIC)

\begin{tabular}{ccccc}
\hline Dependent variable & Independent variable & F-statistic & Lower bound, & Upper bound, I(1) \\
$\ln \mathrm{GDP}$ & $\begin{array}{c}\ln (0), \ln F D I, \ln C \mathrm{~T}, \ln \mathrm{PL} \\
\text { (C+Exogenous variables) }\end{array}$ & $8.24 * * *$ & 3.725 & 4.94 \\
\hline
\end{tabular}

Note: Critical values are taken from Narayan (2005). ${ }^{* * *}$ indicates significance at $1 \%$ significance level. Source: computed by authors using Eviews9.

Since the ARDL Bounds Test statistic in Table 4, 8.24, which is greater than the I(1) bound critical value, then there is a long-run cointegration relationship between lnGDP and the independent variables at $5 \%$ significance level. According to the AIC, the optimal model is selected to be ARDL $(4,3,0,1,0)$. The error correction model is as the following: 
Table 5. Error Correction Model (Short-Run Model)

\begin{tabular}{cc}
\hline $\begin{array}{c}\text { Dependent Variable: } \ln \text { GDP; Optimal Model: ARDL } \\
\text { Variable }\end{array}$ & Coefficient \\
\hline C & $1.506^{* * *}$ \\
D(LNGDP) & $0.124^{*}$ \\
D(LNGL) & -0.013 \\
D(LNCT) & $0.039^{*}$ \\
DUMLNCT & -0.037 \\
DUMLNFDI & $0.078^{* * *}$ \\
DUMLNGL & -0.0212 \\
DUMLNPL & 0.026 \\
CointEq(-1)* & $-0.31787 * * *$ \\
\hline Test Stats & Diagnostic tests: \\
\hline Breusch-Godfrey Serial Correlation LM Test & $0.2855[0.5931]$ \\
Heteroskedasticity Test: ARCH & $0.011[0.92]$ \\
Normality Test (Jarque-Bera) & $1.617[0.446]$ \\
\hline
\end{tabular}

Note: t-statistics are given in parentheses. $* * * *, * *$ and $*$ indicate significance at the $1 \%, 5 \%$ and $10 \%$ significance levels, respectively. Probability values are in brackets.

Source: computed by authors using Eviews9.

According to the results, there exists an only short-run causality from current transfers to GDP at $10 \%$ level. In the short-run, current transfers affects GDP positively, which is consistent with the expectations. The coefficient of the lagged ECT is negative and statistically significant even at $1 \%$ level, which does support what we have found in the ARDL bounds test. At least, $31.787 \%$ of the disequilibria in the short-run is cancelled in one quarter. So, the speed of adjustment is moderate. Half of the disequilibria is cancelled in $\mathrm{t} 1 / 2=0.693 / 0.31787 \approx 2.18$ quarters or about 6 and a half months.

As a result of diagnostic tests, there is no serial correlation and heteroscedasticity problems in the error terms obtained in the model and they are normally distributed as well. So, the estimators are unbiased and standard errors are valid such that the inferences can be done about the population parameters. Lastly, let's check the stability of the estimators by using CUSUM test:

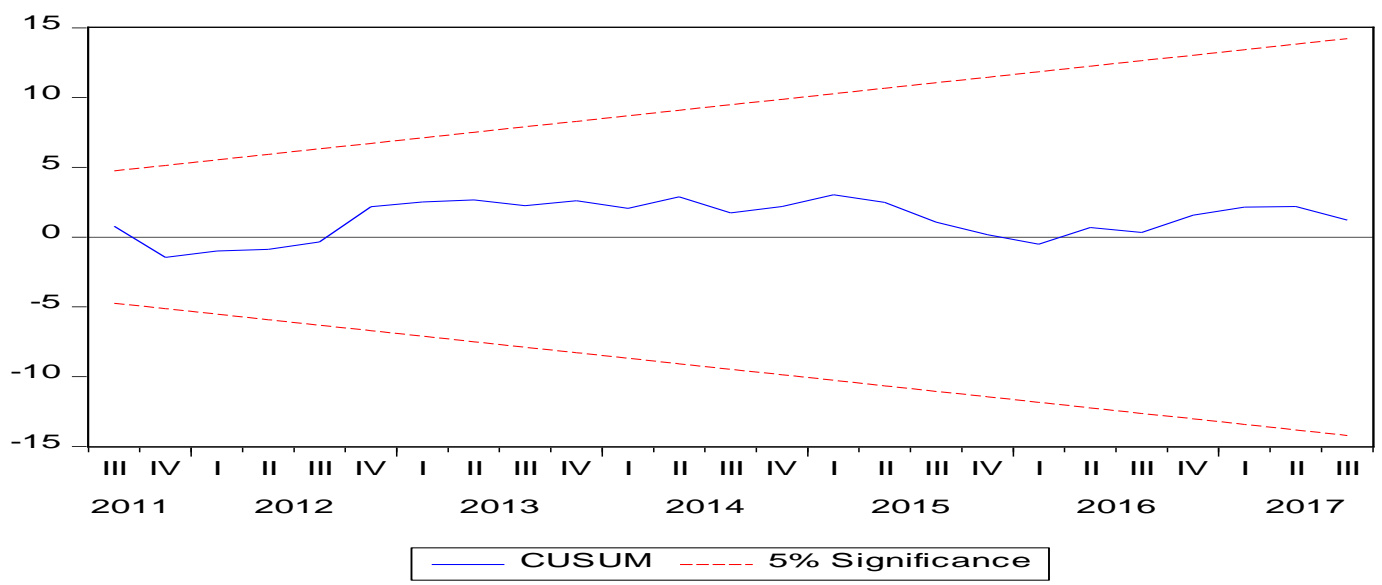

Figure 1. CUSUM Test Results

Since the line is within the $5 \%$ significance region, the estimates are dynamically stable. In conclusion, the error terms are well-behaved, and estimates are good estimates in a sense that they are BLUE, and dynamically stable.

When the long-term relationships are examined, it is seen that the coefficients of the explanatory variables participating in the model and the whole of the constant term have a positive value. 
All coefficients except of lnFDI are significant at 1\% level. According to these results, every 1\% increase in loans to government, foreign direct investments, current transfers from abroad, and loans to private sector leads to about $0.167 \%, 0.046 \%, 0.23 \%$, and $0.067 \%$ increases in GDP respectively in the long-run.

Table 6. Long-Term Coefficients

\begin{tabular}{ccc}
\hline & Dependent Variable: lnGDP & Coefficient \\
\hline Variable & $0.1665^{* * *}$ \\
LNGL & $0.0462^{* *}$ \\
LNFDI & $0.2251^{* * *}$ \\
LNCT & $0.0672^{* * *}$ \\
LNPL & & \\
\hline
\end{tabular}

Note: t-statistics are given in parentheses. ${ }^{* * *},{ }^{* *}$ and $*$ indicate significance at the $1 \%, 5 \%$ and $10 \%$ levels, respectively.

Source: computed by authors using Eviews9.

Nevertheless, external debt to Kyrgyzstan is often used in two ways: a) social spending such as education and health; b) investment expenditures such as roads, bridges, buildings. While social expenditures trigger more imports by increasing aggregate demand, it can be said that the contribution of the economy to the infrastructural investments is more important. Moreover, the efficiency of the use of external debt is not as expected. More importantly, external debt has been a significant burden on the state budget and on the national economy during the repayment period. Therefore, more attention should be paid to remittances and mainly to foreign direct investments.

\section{Conclusion and Policy Recommendations}

The external debt of the Kyrgyzstan state has risen by $86 \%$ in the last ten years, from 2.07 to 3.86 billion US dollars. The majority of the foreign debt of Kyrgyzstan owes to China Export-Import Bank, the World Bank and the Asian Development Bank with the share of $44.5 \%, 18.2 \%$ and $16.7 \%$ respectively. A significant portion of these resources was used infrastructural investments such as electricity and roads.

Total external debt of 3.5 billion dollars consisted of $58.4 \%$ bilateral privileged and $40.2 \%$ multilateral privileged loans. That is, $98.6 \%$ of the total debt consists of privileged debt. It should not be forgotten that even though this seems to be positive for the country's economy, due to its longer duration and lower interest rates, it still owes its debts. Therefore, more emphasis should be placed on attracting private capital in the form of public-private partnership in the upcoming period for infrastructure investments. This, in our view, is one of the important measures that could prevent the total external debt from increasing more rapidly.

On the other hand, according to the data of the National Statistical Committee of the Kyrgyz Republic, the amount of foreign direct investments in Kyrgyzstan during the period of 1995-2016, reached to 9.89 billion US dollars. Looking at the average of the last ten years, there is an investment of about 800 million US dollars per year.

The largest investor countries and their proportion of the total are, respectively, as follows: Canada, China, Kazakhstan, Russia, United Kingdom, Turkey, Germany and the USA. Investments generally come to the industry and service sectors especially such as food, construction, banking, mining, trade, and education have become more prominent.

When empirical studies examining the effects of external debt and FDI on economic growth are summarized, foreign debts have contributed positively to the economic growth of some countries, while some countries have negatively affected their growth; whereas FDI was generally positive to grow and in some cases had no effect.

Based on the theoretical and empirical studies like this, the effect of external debt, current transfers and FDI on economic growth in Kyrgyzstan was investigated in this study. As a result of the research, it is found that the country's economy is dependent mainly on foreign financing sources which are ineffective from the long-term point of view and that FDIs cannot make a meaningful contribution to the economy.

From the results of the analysis it is suggested that the government has to focus more on FDIs than foreign debts and current transfers in the long term. It is clear that more effective policies should be 
pursued to canalize domestic and foreign private capital to infrastructural investments such as highways and dams, in particular by "public-private partnership" method. Also government should develop mechanisms for directing remittances to the real sector. In addition, it is necessary to improve the investment climate for internal and external investors. In particular, remove bureaucratic barriers, eradicate corruption and guarantee the protection of investor rights.

\section{References}

Abdelhafidh, S. (2014). External debt and economic growth in tunisia. Panoeconomicus, 6, 669-689. doi: 10.2298/PAN1406669A.

Acar, M. (2016). Doğrudan yabancı sermayenin ekonomik büyümeye etkisi: Türkiye örneği. Kastamonu Üniversitesi İktisadi ve İdari Bilimler Fakültesi Dergisi, 13, 92-105.

Afşar, M. (2008). The causality relationship between economic growth and foreign direct investment in Turkey. Selcuk Üniversitesi Sosyal Bilimler Enstitüsü Dergisi, 20, 1-9.

Akbas, Y.E., Senturk, M., \& Canan, S. (2013). Testing for causality between the foreign direct investment, current account deficit, GDP and total credit: Evidence from G7. Panoeconomicus, 6, 791-812. doi: 10.2298/PAN1306791A.

Alfaro, L., \& Charlton, A. (2007). Growth and the quality of foreign direct investment: Is all FDI equal? CEP Discussion Paper, No.830, November.

Anwar, S., \& Nguyen, L.P. (2010). Foreign direct investment and economic growth in Vietnam. Asia Pacific Business Review, 16(1-2), 183-202. doi: 10.1080/10438590802511031.

Azeez, B., Oladapo, F., \& Olufemi, A. A. (2015). External debt or foreign direct investment: which has greater significant economic impact on Nigeria? European Scientific Journal, 11(19), 185-195.

Bakar, N. A., \& Sallahuddin, H. (2008). Empirical evaluation on external debt of Malaysia. International Business \& Economics Research Journal, 7(2), 95-108. doi: 10.19030/iber.v7i2.3226.

Balasubramanyam, N., Solisu, M., \& Sapsford, D. (1996). Foreign direct investment in EP and IS Countries. The Economic Journal, 106(434), 92-105.

Basu, P., Chakraborty, Ch., \& Reagle, D. (2003). Liberalization, FDI and growth in developing countries: A panel cointegration Approach. Economic Inquiry, 41(3), 510-516. doi: 10.1093/ei/cbg024.

Bilginoğlu, M. A., \& Aysu, A. (2008). Dış borçların ekonomik büyüme üzerindeki etkisi: Türkiye örneği. Erciyes Üniversitesi İktisadi ve İdari Bilimler Fakültesi Dergisi, 31, 1-23.

Çeştepe, H., Yıldırım, E., \& Bayar, M. (2013). doğrudan yabancı yatırım, ekonomik büyüme ve dış ticaret: TodaYamamoto yaklaşımıyla Türkiye'den nedensellik kanıtları. Akdeniz Üniversitesi İktisadi ve İdari Bilimler Fakültesi Dergisi, 13(27), 1-37.

Dickey, D.A., \& Fuller, W.A. (1979). Distribution of the Estimators for Autoregressive Time Series with a Unit Root. Journal of the American Statistical Association, 74, 427-431.

Dönmez, A. (2009). Doğrudan yabanc sermaye yatırmlarmm ekonomik büyüme ve dşs ticaret üzerine olan etkileri: Türkiye üzerine bir uygulama (Unpublished Master Thesis) (in Turkish). Çukurova Üniversitesi Sosyal Bilimler Enstitüsü İktisat Anabilim Dalı, Adana.

Gül, E., Kamacı A., \& Konya, S. (2012). Dış borcun büyüme üzerine etkileri: Orta Asya Cumhuriyetleri ve Türkiye örneği. Proceedings Book of International Conference on Eurasian Economies. pp. 169-174.

Gürdal, T., \& Yavuz, H. (2015). Türkiye'de diş borçlanma-ekonomik büyüme ilişkisi: 1990-2013 Dönemi. Maliye Dergisi, 168, 154-169.

Hamilton, J. D. (1994). Time series analysis. Princeton University Press.

Hsiao, C., \& Shen, Y. (2003). Foreign direct investment and economic growth: The importance of institutions and urbanizations. Economic Development and Cultural Change, 51(4), 883-896. doi: 10.1086/375711.

Jilenga, M.T., Xu, H., \& Gondje-Dacka, I.M. (2016). The impact of external debt and foreign direct investment on economic growth: Empirical evidence from Tanzania. International Journal of Financial Research, 7(2), 154162. doi: $10.5430 /$ ijfr.v7n2p154.

Karagoz, M., \& Caglar, M. (2016). Does debt really crack the whip? Evidence from a panel of selected OECD countries. Procedia Economics and Finance, 38, 430-437. doi: 10.1016/S2212-5671(16)30214-3.

Kempa, B., \& Nazmus, S.K. (2016). Government debt and economic growth in the G7 countries: Are there any causal linkages? Applied Economics Letters, 23(6), 440-443. doi: 10.1080/13504851.2015.1080797.

Kutlu, S., \& Yurttagüler, İ. M. (2016). Türkiye’de diş borç ve ekonomik büyüme ilişkisi: 1998-2014 dönemi için bir nedensellik analizi. M. U. İktisadi ve İdari Bilimler Dergisi, 38(1), 229-248. doi: 10.14780/iibd.69945.

Lensink, R., \& Morrissey, O. (2001). Foreign direct investment: flows, volatility and growth in developing countries. Research Report 01E16, University of Groningen, Research Institute SOM (Systems, Organisations and Management).

MacKinnon, J. G. (1991). Critical values for cointegration tests. Chapter 13 in R. F. Engle \& C. W. J. Granger (Edt.), Long-run economic relationships: readings in cointegration. Oxford: Oxford University Press.

MacKinnon, J. G. (1996). Numerical Distribution Functions for Unit Root and Cointegration Tests, Journal of Applied Econometrics, 11, 601-618.

Narayan, P. K. (2005). The saving and investment nexus for China: Evidence from cointegration tests. Applied Economics, 37(17), 1979-1990. doi: 10.1080/00036840500278103. 
Nelson, C. R., \& Plosser, C. I. (1982). Trend and random walks in macroeconomic time series. Journal of Monetary Economics, 10, 139-162.

Ogunmuyiwa, M.S. (2011). Does external debt promote economic growth in Nigeria?. Current Research Journal of Economic Theory, 3(1), 29-35.

Örnek, İ. (2008). Yabancı sermaye akımlarının yurtiçi tasarruf ve ekonomik büyüme üzerine etkisi: Türkiye örneği. A.Ü. SBF Dergisi, 63(2), 199-207.

Perron, P. (1989). The great crash, the oil price shock and the unit root hypothesis. Econometrica, 57, 1361-1401.

Pesaran, H. M., \& Pesaran, B. (1997). Working with microfit 4.0, interactive econometric analysis. Oxford: Oxford University Press.

Pesaran, H. M., Shin, Y., \& Smith, R. J. (2001). Bounds testing approaches to the analysis of level relationships. Journal of Applied Econometrics, 16(3), 289-326. doi: 10.1002/jae.616.

Pesaran, H. M., \& Shin, Y. (1999). Autoregressive distributed lag modelling approach to cointegration analysis. Econometrics and Economic Theory in the 20th Century: The Ragnar Frisch Centennial Symposium. Cambridge: Cambridge University Press.

Phillips, P. C. B., \& Perron, P. (1988). Testing for a unit root in time series regression. Biometrika, 75, 335-346.

Siddique, A., Selvanathan, E. A., \& Selvanathan, S. (2015). The impact of external debt on economic growth: Empirical evidence from highly indebted poor countries. The University of Western Australia, Economics, No 15-10, Economics Discussion / Working Papers, (Available at: https:/ / econpapers.repec.org/paper/uwawpaper/15-10.htm, Accessed: 3 October 2017)

Vergil, H., \& Karaca, C. (2010). Gelişmekte olan ülkelere yönelik uluslararası sermaye hareketlerinin ekonomik büyüme üzerindeki etkisi: panel veri analizi. Ege Akademik Bakıs, 10(4), 1207-1216. doi: 10.21121/eab.2010419606.

Yalçın, E. (2005). İktisadi Büyüme ve Dış Krediler: Ampirik Bir Çalısma. Research Notes in Economics (in Turkish). Central Bank of the Republic of Turkey.

Zaman, R., \& Arslan, M. (2014). The role of external debt on economic growth: Evidence from Pakistan economy. Journal of Economics and Sustainable Development, 5(24), 140-148.

Zivot, E., \& Andrews, D. (1992). further evidence of great crash, the oil price shock and unit root hypothesis. Journal of Business and Economic Statistics, 10, 251-270.

\section{TÜRKÇE GENIŞ ÖZET}

Kırgızistan küçük, dışa açık, petrol ürünlerinde dişa bağımlı ve sanayisi gelişmemiş bir ülkedir. Temel ihraç ürünleri altın, hayvan, meyve ve sebzeler gibi ham ve işlenmemiş mallardan oluşmaktadır. İthalat ihracattan yaklaşı üç kat daha fazladır. İstihdam olanaklarının kısıtlı olması nedeniyle işgücünün üçte birinden fazlası yurtdışında çalışmak zorunda kalmaktadır.

Bunun gibi nedenlerden dolayı ülkenin ekonomik kalkınması dışa bağımlı hale gelmiştir. Dış borçlar, işçi dövizleri ve doğrudan yabancı yatırımlar ekonomik büyümeye önemli katkı sağlamaktadır. Bu bağlamda bu çalışmada dış kaynakların ve özellikle dış borçların büyümeye etkisi araştırlarak politika önerileri sunulması amaçlanmıştır.

Günümüzde Kırgızistan ekonomisi dış borçlar, doğrudan yabancı yatırımlar ve işçi dövizleri gibi dışsal büyüme kaynaklarına dayanıyor gibi gözükmektedir. Bunun temel nedenlerinden biri iç kaynakların yetersizliğidir. Bugün devlet tarafından gerçekleştirilen çoğu altyapı yatırımları dış yardım ve borçlar ile finanse edilirken, özel yatıımların da önemli bir kısmı yabancı sermayeden oluşmaktadır. Dış yardımların payı küçük olduğundan dolayı altyapı yatırımları sürekli olarak gelecek kuşakların dış borç yükünü artırmaktadır. Gerçek şu ki Kırgız devletinin dış borçları son on senede 2,07 milyardan 3,86 milyar dolara çıkarak \%86 oranında bir artış kaydetmiş̧ir. Kırgızistan'ın dış borçlarının ülkelere ve kurumlara göre dağılımına bakıldığında, Çin İhracat ve İthalat Bankası’nın \%44,5'lik bir payla birinci sıraya çıktı̆̆ görülmektedir. Ülkemizin söz konusu kuruma olan borcu son beş senede çok hızlı bir artış kaydetmiştir. $\mathrm{Bu}$ kaynaklar elektrik ve karayolları gibi altyapı yatırımlarına kullanılmış̧ır. İkinci ve üçüncü sıralarda \%18,2’lik bir payla Dünya Bankası ve \%16,7'lik bir payla Asya Kalkınma Bankası gelmektedir. Söz konusu kaynakların da önemli bir kısmı karayolu yatırımlarına yönlendirilmiştir.

Toplam dış borcun \%58,4'ü iki taraflı imtiyazlı, \%40,2'si de çok taraflı imtiyazlı kredilerden oluşmaktadır. Yani toplam borcun \%98,6'sı imtiyazlı borçlardan oluşmaktadır. Sürelerinin daha uzun ve faiz oranlarının daha düşük olması nedeniyle bu durum ülke ekonomisi açısından olumlu gibi gözükmesine rağmen, bunların sonuçta ödenmesi gereken borçlar olduğu da unutulmamalıdır.

Kırg1z Cumhuriyeti Milli İstatistik Komitesi verilerine göre, 1995-2016 döneminde ülkeye gelen doğrudan yabancı yatırımların toplam hacmi 9,89 milyar dolara ulaşmıştır. Bunun beşte biri, yani 1,79 milyar doları mevcut anonim şirketlere ortak olma veya yeni anonim şirketi kurma; \%20'si yeniden yatırım; 
\%44’ü, yani 3,99 milyar doları yabanc1 sermaye sahiplerinden gelen borçlar; \%14,6’sı ticari krediler; \%1,65’i finansal kiralama ve diğer sermaye yatırımları şeklinde gelmiştir. Doğrudan yabancı yatırımların ortalama ylllı hacmi son on senede yaklaşı 800 milyon doları oluşturmuştur.

Ülkeler bazında bakıldığında en büyük yatırımcı ülkeler ve onların toplamdaki payları sırasıyla şu şekildedir: Kanada, Çin, Kazakistan, Rusya, Birleşik Krallık, Türkiye, Almanya ve ABD. Yatırımlar genel olarak sanayi ve hizmet sektörlerine gelmektedir. Onların içinde özellikle gıda, inşaat, bankacılık, madencilik, ticaret, eğitim gibi sektörlerin daha ön plana çıtı̆ğı söylenebilir.

Ekonomik kalkınmayı hedefleyen çoğu ülkeler iç kaynakların yetersizliği sorunuyla karşı karşıya kalarak dış kaynaklara başvurmaktadır. İki temel dış kaynak dış borçlar ve doğrudan yabancı yatırımlardır. Doğrudan yabanc1 yatırımlar dış borçlara göre ülkeye önemli avantajlar sağladığ için, ülkeler dış yatırımcıları çekmeyi tercih etmektedirler. Fakat bazı ülkeler özellikle altyap1 yatırımlarına ya da bütçe açığını kapatmaya kaynak bulamadığı durumlarda dış borçlara başvurmaktadırlar.

Bununla birlikte, dış borçların ekonomik büyümeye etkileri konusunda hem teorik hem de empirik çalışmalarda fikir birliği bulunmamaktadır. Bu konuda teorik literatür daha çok 1980’lerde Latin Amerika'daki borç krizi sonrası gelişmiştir. Bunlara örnek olarak zamanlararası borçlanma modeli, borçla büyüme modeli ve borç fazlası teorisi gibi yaklaşımlar gösterilebilir.

Empirik çalışmalara göre, dış borçlar bazı ülkelerde ekonomik büyümeye pozitif katkıda bulunurken, bazılarında büyümeyi negatif etkilemektedir. Sadece dış borcun ekonomik büyümeye etkisini araştıran çalışmalardan HIPC ülkeleri ve Türkiye üzerine yapılan bazı çalışmalar dış borcun büyümeyi olumsuz etkilediğini tespit etmiştir. Diğer taraftan, gelişmekte olan ülkeler üzerine yapılan birçok empirik çalışma dış borcun büyümeye olumlu katkı sağladığı sonucuna ulaşmıştır. Bazılanı da böyle bir sonucun etkin borç yönetiminden kaynaklanabileceği görüşünü belirtmişlerdir. Doğrudan yabanc1 yatırımların ise büyümeyi genelde pozitif etkilediği ve bazı durumlarda net bir etkisinin görülmediği tespit edilmiştir.

Kırgızistan örneğinde bu konuda zaman serileri kullanılarak yapılan empirik bir çalışma yoktur. Türk Cumhuriyetleri üzerine yapılan tek bir panel veri çalışmasına rastlanmıştır. Söz konusu çalışma sadece dış borçların büyümeye etkisini araştırarak dış borçlardan büyümeye doğru tek yönlü bir uzun dönem nedensellik ilişkisinin olduğunu ortaya koymuştur.

Bundan dolayı hem bu çalışmanın sonuçlarını test etmek hem de Kırgız Cumhuriyeti'nde doğrudan yabancı yatırımların ve dış borçların ekonomik büyümeye etkisini araştırmak amacıyla bu konu seçilmiştir.

2000Q1-2017Q3 dönemi çeyrek verileri ve ARDL eşbütünleşme yaklaşımı kullanılarak yapılan analiz sonucunda cari transferler, dış borçlar ve doğrudan yabancı yatırımlar ile Gayri Safi Yurtiçi Hasıla arasında eşbütünleşmenin olduğu ortaya konmuştur. Çalışma sonucunda ülke ekonomisinin uzun dönem pespektifinde bakıldığında etkin olmayan dış kaynaklara dayandığı ve doğrudan yabancı yatırımların ekonomiye önemli bir katkı sağlamadığı tespit edilmiştir.

Çalışmada elde edilen sonuçlardan yola çıkılarak, hükümetin dış kaynak seçiminde uzun dönemi düşünerek dış borçlar ve cari transferlere göre daha çok doğrudan yabancı yatırımlara ağırlık vermesi önerilmektedir. Özellikle "kamu özel işbirliğì" yöntemi gibi mekanizmalarla karayolu, baraj gibi altyap1 yatırımlarına yerli ve yabancı özel sermayeyi çekme konusunda daha etkin adımların atılması gerekmektedir. 
APPENDIX 1 - Distribution of Kyrgyzstan's State External Debt by Country and Institutions, million USD.

\begin{tabular}{|c|c|c|c|c|c|c|c|c|c|}
\hline & 2000 & 2005 & 2010 & 2011 & 2012 & 2013 & 2014 & 2015 & 2016 \\
\hline $\begin{array}{l}\text { BILATERAL } \\
\text { CONCESSIONAL } \\
\text { LOANS }\end{array}$ & 183.6 & 239.2 & 792.4 & 930.0 & 1148.0 & 1321.6 & 1645.3 & 1825.4 & 1988.8 \\
\hline $\begin{array}{l}\text { China Export-Import } \\
\text { Bank }\end{array}$ & 0.0 & 13.9 & 150.9 & 272.6 & 527.5 & 758.4 & 1115.9 & 1296.4 & 1482.8 \\
\hline $\begin{array}{l}\text { Japan International } \\
\text { Cooperation Bank }\end{array}$ & 183.6 & 225.2 & 341.4 & 357.4 & 320.6 & 263.1 & 229.4 & 229.0 & 236.0 \\
\hline Russian Federation & 0.0 & 0.0 & 300.0 & 300.0 & 300.0 & 300.0 & 300.0 & 300.0 & 270.0 \\
\hline Others & 44.6 & 74.8 & 102.5 & 102.2 & 116.3 & 196.1 & 222.8 & 235.1 & 221.3 \\
\hline $\begin{array}{l}\text { BILATERAL NON- } \\
\text { CONCESSIONAL } \\
\text { LOANS }\end{array}$ & 207.2 & 232.3 & 243.1 & 239.5 & 188.9 & 0.0 & 0.0 & 0.0 & 0.0 \\
\hline Russian Federation & 166.2 & 186.0 & 193.6 & 190.3 & 188.9 & 0.0 & 0.0 & 0.0 & 0.0 \\
\hline $\begin{array}{l}\text { Export-Import Bank of } \\
\text { Turkey }\end{array}$ & 41.0 & 46.3 & 49.5 & 49.2 & 0.0 & 0.0 & 0.0 & 0.0 & 0.0 \\
\hline Others & 27.7 & 28.6 & 10.9 & 11.0 & 11.0 & 11.2 & 10.1 & 9.3 & 8.9 \\
\hline $\begin{array}{l}\text { MULTILATERAL } \\
\text { CONCESSIONAL } \\
\text { LOANS }\end{array}$ & 805.3 & 1230.7 & 1390.2 & 1425.7 & 1460.0 & 1506.9 & 1440.3 & 1402.9 & 1374.1 \\
\hline $\begin{array}{l}\text { International Monetary } \\
\text { Fund (IMF) }\end{array}$ & 187.9 & 205.6 & 176.7 & 181.8 & 190.5 & 202.7 & 185.2 & 188.2 & 188.0 \\
\hline $\begin{array}{l}\text { Asian Development } \\
\text { Bank (ADB) } \\
\text { International }\end{array}$ & 241.2 & 466.9 & 564.2 & 583.4 & 594.6 & 607.1 & 583.6 & 575.4 & 567.9 \\
\hline $\begin{array}{l}\text { Development } \\
\text { Association (IDA - } \\
\text { World Bank Group) }\end{array}$ & 376.1 & 558.3 & 649.4 & 660.5 & 674.8 & 697.1 & 671.5 & 639.3 & 618.2 \\
\hline $\begin{array}{l}\text { Others } \\
\text { MULTILATERAL }\end{array}$ & 22.9 & 48.9 & 70.8 & 78.3 & 77.8 & 82.9 & 78.0 & 87.5 & 107.2 \\
\hline $\begin{array}{l}\text { NON- } \\
\text { CONCESSIONAL } \\
\text { LOANS } \\
\text { Central Asian }\end{array}$ & 16954.0 & 43254.0 & 42461.0 & 15.4 & 29.6 & 40.0 & 40.6 & 41.0 & 42.5 \\
\hline $\begin{array}{l}\text { Cooperation and } \\
\text { Development Bank } \\
\text { European Bank for }\end{array}$ & 0.0 & 0.0 & 0.0 & 0.0 & 0.0 & 0.0 & 0.0 & 0.0 & \\
\hline $\begin{array}{l}\text { Reconstruction and } \\
\text { Development (EBRD) } \\
\text { CREDITS }\end{array}$ & 16954.0 & 43254.0 & 42461.0 & 15.4 & 29.6 & 40.0 & 40.6 & 41.0 & 42.5 \\
\hline $\begin{array}{l}\text { RECEIVED UNDER } \\
\text { GOVERNMENT } \\
\text { GUARANTEE }\end{array}$ & 98.6 & 24.7 & 1.6 & 0.6 & 0.0 & 0.0 & 0.0 & 0.0 & 0.0 \\
\hline TOTAL & 1301.1 & 1729.9 & 2431.5 & 2611.2 & 2826.6 & 2868.4 & 3126.2 & 3269.3 & 3405.4 \\
\hline
\end{tabular}

